\title{
Perceptions of caregivers about surgical children's thirst
}

\author{
Percepção dos cuidadores quanto à sede da criança cirúrgica
}

\author{
Percepción de los cuidadores cuanto a la sed del niño quirúrgico
}

\author{
Mariana Campos Campana ${ }^{1}$, Lígia Fahl Fonseca ${ }^{1}$, Dolores Ferreira de Melo Lopes ${ }^{1}$, Pamela Rafaela Martins ${ }^{1}$
}

Objective: to understand how caregivers experience surgical children's fasting and how they realize their thirst in the perioperative period. Methods: descriptive study of qualitative nature, carried out with 15 caregivers of children between 1 and 12 years old after surgery in a teaching hospital. For analysis, the Collective Subject Discourse method was used. Results: four thematic units emerged: surgical children in the presence of fasting and thirst; realizing thirst in surgical children; experiencing and facing the period of fasting and thirst with children; realizing the action of the health team in the presence of children's thirst. For families, the experience of fasting is permeated with feelings like helplessness and distress. The presence of thirst, detected by self-report and physical signs, exacerbates their suffering. Conclusion: thirst management alleviates the suffering of children and families. It is therefore necessary to develop strategies for children's thirst management.

Descriptors: Thirst; Fasting; Perioperative Care; Child.

Objetivo: compreender como o cuidador vivencia o jejum da criança cirúrgica e percebe sua sede no período perioperatório. Métodos: pesquisa descritiva de natureza qualitativa, realizada com 15 acompanhantes de crianças entre 1 e 12 anos no pós-operatório em um hospital-escola. Para análise, utilizou-se o método do Discurso do Sujeito Coletivo. Resultados: emergiram quatro unidades temáticas: A criança cirúrgica em face do jejum e da sede; Percebendo a sede na criança cirúrgica; Vivenciando e enfrentando o período de jejum e a sede junto da criança; Percebendo a ação da equipe em face da sede da criança. Para os familiares, a vivência do jejum é permeada de sentimentos, como impotência e angústia. A presença da sede, detectada pelo autorrelato e por sinais físicos, agrava esse sofrimento. Conclusão: o manejo da sede amenizaria o sofrimento da criança e dos familiares. Por conseguinte, é necessário desenvolver estratégias de manejo da sede na criança. Descritores: Sede; Jejum; Assistência Perioperatória; Criança.

Objetivo: comprender cómo el cuidador experimenta el ayuno del niño quirúrgico y percibe su sed en el perioperatorio. Métodos: estudio descriptivo, cualitativo, con 15 cuidadores de niños entre 1 y 12 años en postoperatoria en un hospital universitario. Para el análisis, se utilizó el método del Discurso del Sujeto Colectivo. Resultados: surgieron cuatro unidades temáticas: Niño quirúrgico delante del ayuno y de la sed; Percibiendo la sed en el niño quirúrgico; Experimentar y enfrentarse el ayuno y sed con el niño; Percibiéndose la acción del equipo delante de la sed del niño. Para la familia, la experiencia del ayuno está llena de sentimientos, como impotencia y angustia. La presencia de la sed, detectada por auto-informe y signos físicos, exacerba ese sufrimiento. Conclusión: el manejo de la sed aliviaría el sufrimiento del niño y familias. Por lo tanto, es necesario desarrollar estrategias de manejo de la sed en niño.

Descriptores: Sed; Ayuno; Atención Perioperativa; Niño.

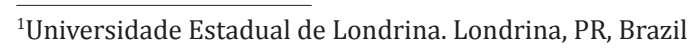

Corresponding author: Mariana Campos Campana

Rua Dinamarca, 955, Centro, CEP: 86181-080, Cambé, PR, Brazil. E-mail: mariicampana@hotmail.com 


\section{Introduction}

For child patients, perioperative is a difficult process, permeated by feelings that end up generating physical and emotional behaviors that cannot be ignored by health teams. Children create fantasies and fears about situations and procedures experienced in the hospital environment. They fear pain, hospital supplies, risks to which they are exposed and even the presence of several doctors in the operating room. The perioperative children therefore require specific care, both physical and emotional ${ }^{(1)}$.

During the pre-operative care, one carries out actions which are aimed at skin decontamination, medication administration and gastrointestinal preparation, which includes the prescription of fasting. The recommended period of fasting varies in patients with morbidity at risk for pulmonary aspiration as well as the food to be ingested. To clear liquids, it is recommended at least two hours before surgery ${ }^{(2)}$.

Fasting is paramount in the preoperative care because it enables the time required for gastric emptying, preventing pulmonary aspiration. However prolonged fasting, usually excessive, generates discomfort to patients. Fluid intake during the preoperative period decreases thirst and hunger in children, which makes the experience more comfortable ${ }^{(3)}$. Children who are encouraged to drink clear liquids up to two hours before surgery have a lower intensity of thirst during 24 hours after surgery, when compared to children who did not receive the same care ${ }^{(4)}$.

The sensation of thirst may have hypovolemic or osmotic origin. The hypovolemic thirst occurs when baroreceptors detect decreased blood volume and release angiotensin II, responsible for the stimulation of thirst in the hypothalamus. In the osmotic thirst, plasma hyperosmolarity makes the intracellular water to be transported to the blood, causing dehydration of the supraoptic neuronal cells, which stimulate the secretion of the antidiuretic hormone. There is, however, a limit of antidiuresis: when the body achieves it, it turns to other ways of rehydration, among them thirst ${ }^{(5)}$.

Perioperative thirst may be more intense in children because of the speed in which they dehydrate. The percentage of liquid in their bodies and their intra and extravascular distribution change with age. In babies and children, the percentage of body water is higher than in adults, and the water content is higher in the extracellular compartment than in the intracellular compartment, which promotes a higher speed of dehydration ${ }^{(6)}$.

Thirst is characterized as a symptom, a subjective manifestation which depends on patients' interpretation and verbalization. Selfreport is important for the proper management of thirst, however nonverbal patients such as small children, need caregivers' help for the perception and interpretation of its symptoms. When evaluating a child, one should take into consideration the caregivers' reports, because it is easy for them to recognize behaviors that show discomfort ${ }^{(7)}$.

Given the above and the lack of studies on the subject, this study aimed to understand how families experience fasting and how they perceive children's thirst during the perioperative period. The results can contribute to the improvement of care of surgical children, who are helpless beings without full understanding of the situation, and to make room for future studies that seek management strategies of surgical children's thirst.

\section{Method}

This is a descriptive and qualitative study developed between April and June 2014 in a large university hospital in northern Paraná, which serves only the Unified Health System and performs an average of 600 surgeries per month. The participants of the study were companions of children who had undergone surgery and were recovering in the infirmary between 5 and 12 hours after the procedure. The sample consisted of 15 participants, in this 
case, mothers and grandmothers, and the inclusion criteria were: being a family member of the child, monitoring the child's hospitalization during the pre and post-operative period in the infirmary, being able to answer the questions asked and agreeing to participate. The child accompanied should be from 1 to 12 years old and have undergone elective or emergency surgery, under general anesthesia or sedation, regardless of fasting time. The exclusion criterion was children who had been fed by gastrostomy, nasogastric or parenteral tube.

The researcher collected speeches through semi-structured interviews, lasting an average of 15 minutes, which occurred in the infirmary. The interview, recorded in a digital recorder, had two guiding questions: How was the experience of the child's fasting for surgery? How was to experience the child's thirst during this period? There were two pilot tests to practice and improve the interviewing technique. For a better understanding of the meaning of the questions, one added the following questions: What did you feel when you saw the child during fasting? What happened in that period?

For the analysis of the interviews, we used the Collective Subject Discourse, which consists in the creation of a synthesis speech that expresses the opinion of a collectivity about the studied subject. The interviews, after being transcribed, were analyzed descriptively in search of the key ideas, anchors and key phrases. When these methodological figures were found, data were interpreted and gathered in one single speech, which is the perception of families before the children's thirst and fasting ${ }^{(8)}$.

After the reading and data analysis, four thematic units considered relevant to this study emerged: Surgical children in the presence of fasting and thirst; Realizing thirst in surgical children; Experiencing and facing the period of fasting and thirst with children; Realizing the action of the health team in the presence of the child's thirst.

The participants were identified only by the initial letter of their relationship with the hospitalized child, M for mother and G for grandmother, then the number of interview order. The project was approved by the university research ethics committee under number 617,255.

\section{Results}

Participants were 15 women - 13 mothers and two grandmothers - aged between 19 and 59 years old. As for education, one of them had completed technical education, seven had completed high school and the others had finished elementary school. Regarding the children, their ages ranged from 1 to 12 years old, all of them received general anesthesia and underwent urgency surgeries of different specialties. Concerning the fasting period, the total time reported by families ranged from 7 to 73 hours.

\section{Surgical children in the presence of fasting and thirst}

Children who require preoperative fasting may not understand the importance of this procedure, making it difficult to adhere and maintain it in a peaceful and spontaneous way: He did not understand why he could not have water. For a child it is more difficult to understand why not. But we adults who have already undergone [surgery], we know we have to go through it. I said that he couldn't but he didn't understand it, the risk involved (M4, M5, M11).

Caregivers realize a series of feelings and reactions triggered by not understanding the need for fasting: nervousness, sadness, crying, restlessness and abdominal pain: Oh... he was very nervous, because he wanted to eat, wanted to drink water and he couldn't, he asked for food all the time, he wanted to be breastfed... He was very upset, sad, anxious, distressed. He kept saying he was hungry, a little bit stressed out, angry, he kept crying... It was terrible, all day long complaining. He was like, Oh, mom, my stomach hurts, I'm hungry! He became restless and asked to leave, he did not want to undergo surgery, that he was good the way he was, you know? Then he cried, he squeezed my hand... It's a lot of suffering (M1, G3, M4, M7, M9, M11, M12, M13, M14). On the other hand, when child patients 
are oriented by the health team, they are able to understand and experience more smoothly the perioperative fasting: The doctors arrived and explained it to him, always talking and he understood it, he knew that he had to wait for the right time, ok? Oh, he was pretty calm considering the situation, right? He was normal, quiet... We just needed to talk to him... I talked to him, explained that it was for his own good. He behaved well, he did not insist to drink water or to eat. He stayed calm, he did not cause any trouble at all .He understood it very well (M2, M6, M8, M10, G15, G3).

\section{Realizing thirst in the surgical child}

During the period of perioperative fasting of pediatric patients, thirst is a discomfort very present and perceived by caregivers: The hardest part was the thirst, he could not drink water, He gave me a hard time asking for water. Regarding eating, he said nothing: the problem was water. He cried because he wanted water, but he couldn't! He got nervous, he wanted water, especially water, he just asked for water, lots of water, but the rest was ok. (G3, M5, M6, M7, M11).

One can see in some way and at some point, that the patient is thirsty, especially through self-report, when he complains of thirst or asks for water: He was thirsty, he asked for water, lots of water, he said that he wanted water, that he was very thirsty. He asked all the time, saying he was thirsty, he wanted water, water, water... He asked a lot, saying: Can you give me sip of water? He kept asking all the time (M1, M2, G3, M4, M5, M6, M7, M8, M9, M11, M12, M14, M15). He was thirsty because at the time he went downstairs, I gave him a cup of water, he drank it fast, you know, and he wanted more (M13).

In some periods, children may not realize or mention thirst. Still, caregivers notice physical signs: dry and whitish lips, constantly swallowing saliva, sore throat and behavior of searching for water when their lips were moistened by someone. Interviewees reported having noticed clear signs like dryness of the lips and of the oral cavity: I was going to wet his mouth, I noticed that he wanted it into his mouth. Then I had to keep shutting his mouth (M5). He opened his mouth and swallowed saliva, you know, you could tell he was thirsty. He swallowed only saliva (M10).
He said that his throat hurt, I think it was dry (M9). His little mouth was all dry and his lips cracked, as if he had never drunk water. He kept licking his lips! His lips got all cracked from the lack of water. The dry mouth was very white (M1, M2, M4, M5, M6, M8, M9, M10, M11, M12).

Prolonged fasting time may influence in the presence of thirst. Some children who underwent appendectomy reported thirst in the postoperative period and stayed, according to their companions, a long period without eating after the procedure; one of them stayed two days without drinking liquids. The last time he ate and drank water was on Thursday afternoon, and the surgery was on Saturday morning. He stayed all this time without drinking water, without eating anything. It was hard, because after the surgery, he spent three days without eating anything; They allowed water gradually. He spent a couple of days without drinking water (M1, M2, M5, M10, M14).

Environmental and physical factors such as heat, intubation and the use of nasal packing, also contribute to dry mouth: He felt very thirsty and it was hot so, it was awful (M14). [Thirst] worsens a lot after [the surgery], because they put a kind of pacifier in their mouth that goes until the throat and keeps the mouth open, it made the poor thing completely dry (M11). Because he was with the [nasal] cap, he breathed with his mouth open all the time, his mouth started to crack, got dry (M14).

Individual aspects of children are also involved in the experience of thirst. Some mothers reported that their children felt intense thirst due to the habit of drinking a lot of water at home: He carries a water bottle with him all day long, he goes to sleep and takes the water together, then I believe that his thirst was hard, because he is used to drinking lots of water (M4, M11, M12).

\section{Experiencing and facing the period of fasting and thirst together with the child}

Experiencing children's fasting and thirst causes mixed feelings in caretakers. Caregivers reported difficulty in dealing with children's thirst. They mentioned feelings like grief, compassion, sadness and nervousness: It's bad, isn't it? Because we see that 
he is asking, and we can't do anything, We can't give them water. We get nervous when we see him without drinking water. Complicated, isn't it? The heart squeezes. It was sad to see it. We have all feelings at once, want to cry, but we have to hold on, because he can't see us crying. We know children like to drink water and they could not. It is painful, because water is an essential thing, isn't it? Thirst... Oh my God! Water is everything for us, we can't live without water (M1, M2, G3, M4, M5, M6, M7, M8, M9, M11).

One could notice intense suffering of caregivers; some even say they don't want any mother to go through such a situation. Another common feeling reported by them during this period is impotence they would like to do something to relieve the thirst of their children, but they did not know what could be done: If I could somehow alleviate his thirst, I would like to have done it... If there was something else, I could have done it, but then, at that moment, nothing crossed my mind (M7, M9, M10).

When caregivers are informed about the need of fasting most of them understand it, and most do not disrespect the doctor's orders for fear of cancellation of the surgery or the awareness of the risk of children ingesting any food or liquid: What if I gave him water? The doctor would not do the surgery, of course, because it has the vomiting problems that he said... So I did not give him; if he drank water, how would he undergo surgery? (G3, M11).

Caregivers understand the determination of fasting as a way to protect children and reduce the length of stay. Some companions said they had received guidance on pre and post-operative fasting, which helped them understand the reasons for its determination and the risk of not respecting it: They guided me well! Although he asks for water, I have to follow the guidance and not give them water because it is for his own good. It is risky and dangerous. And even after the surgery I know he could not drink water until the deadline set by the doctor. It makes you want to solve the problem, but I know that at that moment, it would not solve it; it would worsen it. I think it would cause more suffering for him, our time in the hospital would be much bigger (G3, M5, M6, M14, M11).

Caregivers consider thirst during fasting a dead end to be experienced by every patient who waits for surgery. Not knowing how to act, they adopt several ways to alleviate their children's suffering. Some interviewees came to change their own eating pattern: I have not managed to eat correctly, thinking that he was without food and I was eating! The food goes down my throat tearing everything apart, you know, it gets stuck. I avoided eating near him. I wanted, but I waited for him to sleep to go there and drink water (M1, M2, G3, M4, M5, M8, M10, M11, M14, G15, M13). We were fasting that day. I was fasting together with him: while he was in the room, I did not eat anything. After the surgery, then I ate something, but before that nothing, so we keep looking... Leaving him without food and we eating?! No way! At the time the food arrived, he was asleep, but even so I could not eat. I did not even think about eating (M6, M7, M9, M12, M14).

Besides the food restriction itself, we observed other behaviors. It is noticed that caregivers try to distract children with toys, television, phone calls and trips inside the hospital, trying to calm them with words of support and encouragement, explaining the situation and procedures repeatedly, in order to calm the little patient down. As a strategy to alleviate both thirst and hunger, some interviewees reported having wetted their children's oral cavity with wet gauze and small amounts of water and they rarely acted according to suggestions of the medical or nursing staff: at times, the initiative was a caregiver's decision, intuitively, with or without permission from the staff: I wetted his little mouth with a little water just to not get too dry... On my own, because I didn't know what to do. I told the nurse that I gave just little water, I told the doctor that I just wetted a little bit her mouth, it was just a little drop of water only to help a little, you know? (M4, M14). I would just take a little bit of water to help him, I told him: Here it is, let's forget a little bit about food. I wetted his mouth but it couldn't be too much water, it was just to wet his mouth (M4).

Without precise guidance from the health team, supported on scientific knowledge, caregivers of child patients may end up acting intuitively, looking for solutions in their own repertoire. It is clear, however, that they need and wish to receive clear guidelines about care and strategies to deal with the children's thirst and hunger. 


\section{Realizing the action of the health team in the presence of children's thirst}

Many of the caregivers said that the children did not receive any care referring to thirst, and that the health team only said that the saline solution would help alleviate this symptom: Nurses always said that the saline solution would relieve his thirst. So nobody did anything. She [the nurse] gave a little water when it was allowed and not a lot, after hours of surgery (G3, M4, M9, M10, M11, M12, M13, M14, G15).

It can be seen from the reports that the professionals involved do not value children's thirst, they do not consider it a discomforting symptom during the perioperative period. There are cases, however, when they offer some water for children during the fasting period, but without using a standardized amount permitting a safe ingestion by patients: The nurse instructed me to give a little water, but not much because he was going to have surgery. I gave him a little cup every time he asked. Sometimes they made a little hole in the cup, to give only a little bit (M2, M8).

In other cases, professionals said that they could moisten children's lips and oral cavity with wet gauze, without drinking the liquid, or guided patients to gargle with water: The doctor said that I could not give him anything, he just said I could wet his little mouth, so I did it to help. She [the nurse] gave me a piece of gauze with a little water to pass on his lip. The nurse said I could put water in her mouth, ask her to gargle and spit it out (M1, M5, M6, M7).

\section{Discussion}

Child patients have difficulty understanding the fasting period. Some children have negative behaviors, get angry, restless, tearful and insist on eating and drinking water while fasting. Giving children explanations and guidelines regarding perioperative routines and the need for certain procedures can make them suffer less and have a calmer behavior ${ }^{(1)}$.
Children's psycho-emotional preparation is paramount to make the experience of hospital procedures less stressful and traumatic. Playful interventions, essential in this process, enable a less hostile environment for patients, as it takes the hospital closer to children's reality, facilitating communication and care. In addition, it is an important means of coping, which generates greater peace and courage to overcome the difficulties of hospitalization ${ }^{(9)}$. However, there aren't specific studies about playful strategies in the management of the stress caused by fasting and thirst in this population.

Thirst is a symptom that intensifies the discomfort and suffering experienced by surgical children. In adults, one verifies thirst in the perioperative period as a real nuisance of high incidence ${ }^{(10)}$ : during the postoperative period, the incidence reaches $75 \%(\mathrm{n}=128)$ and the average intensity (in a scale from 1 to 10 ) reaches $6.1^{(11)}$ and even $8.1^{(12)}$. However little is known about the incidence of perioperative thirst specifically in children.

Children often face excessive periods of fasting, both for solids and liquids, which can intensify their discomfort. During the pre-operative period of dental surgeries, $56.0 \%$ of children reported feeling very hungry, and $27.0 \%$ very thirsty ${ }^{(13)}$.

The experience of the symptom includes the individual's perception, assessment of its meaning and his response to it ${ }^{(7)}$. It was observed that, for children with verbal communication, verbalization is a form of response to the nuisance perceived. Thus, self-report of symptoms is very important for their appropriate management. Most children of this study verbalized the presence of thirst, possibly for not having experienced a previous situation where their thirst was repressed or devalued.

There are certain peculiarities in the regulatory mechanisms of thirst in children because they 
dehydrate faster - although the manifestation of thirst is lower in very young children, such as babies ${ }^{(6)}$. One observed in the caregivers' account that some children did not understand or did not express thirst at certain times. Caregivers, however, detected the presence of this symptom even without their self-report, by means of signals that children presented.

Participants saw clearly the dry mouth as a sign of thirst in children. Xerostomia is also pointed as a thirst sign in patients using mechanical ventilation ${ }^{(14)}$. The mouth humidification reduces thirst because satiety occurs even before the body absorbs the water ${ }^{(5)}$. Pre-absorptive satiety occurs through the activation of the receptors from the mouth and oropharynx which are sensitive to cooling, called Transient Receptor Potential Melastatin 8. With the activation of these receptors, besides the satiation of thirst, there is a cooling effect, bringing a pleasant sensation to individuals ${ }^{(15)}$.

Several factors may influence the presence of thirst, exactly by the multifactorial nature of this symptom. It may be aggravated by prolonged fasting time, both pre and postoperative. It is advocated that liquids without solid pieces can be taken safely up to two hours before surgery ${ }^{(2)}$, but this recommendation is rarely followed.

The experience of thirst is individual and it changes according to personal and environmental characteristics and to the health-disease environment. Within the environmental domain, ones emphasizes the physical, social and cultural variables ${ }^{(7)}$. The warm weather, mentioned by study participants as aggravating for thirst, is included as a physical factor associated with the environment, as well as intubation and the use of nasal packing in the postoperative recovery, conditions also generated by the surgical setting.

Among the individual factors that affect the appearance and perception of symptoms, there are demographic, psychological, sociological and physiological variables ${ }^{(7)}$. The voluntary fluid intake can be influenced by social and emotional issues ${ }^{(16)}$. It was observed in some cases mentioned by caregivers that the high intensity of thirst some children experienced during the perioperative fasting period relates to their habit of drinking lots of water.

It can be noticed, however, that the domains person, environment and the health-disease context are interrelated ${ }^{(7)}$. Individual factors such as habits are conditioned by environmental characteristics as well as social relations; so it is recommended that the evaluation of symptoms, among them thirst, should be done in a multidimensional way, covering all the related aspects jointly.

As for the kids, facing adversities present in surgical hospitalization also causes distress to caregivers. In addition to the fears and uncertainties, many negative feelings come from the discomfort that perioperative fasting entails. The suffering is so strong that some mothers reported they felt like crying. Caregivers find themselves powerless before such an event and would like to be able to give more comfort to children ${ }^{(17)}$.

In order to collaborate with the patient and, in a way, reduce children's suffering, it is observed that caregivers alter their eating pattern or even restrict their food. Going fasting together with the children is a common choice among them: some caregivers get to stay up to 19 hours without eating. In addition, there are cases when parents go out of the anesthetic induction room and feel nausea, dizziness and some even faint. During this period, there are companions who even fail to take their routine medications ${ }^{(18)}$.

Due to the anxiety experienced during fasting and thirst, it becomes evident the search for comfort and encouragement strategies. There is the importance of the maternal presence during children's hospitalization who have their mothers or the person 
who represents this role as a reference in their care and guidance. For infant patients, receiving affection, attention and being in their mother's presence are ways to feel cared for ${ }^{(1)}$.

It was noticed in caregivers' speeches that, although thirst causes discomfort to children and they ask for water, most of the times they do not realize efforts from the nursing staff's to solve or alleviate this problem. The symptom goes unnoticed even if the child does not complain of thirst. Professionals want to diminish the factors that create discomfort for patients, but not always realize when they are thirsty. Moreover, it is common the habit of not writing down the patients' thirst in the nursing prescriptions ${ }^{(14)}$.

There are methods that are proven to relieve the thirst of hospitalized patients: gargling with cold water showed to be effective to decrease thirst and improved the condition of patients' oral cavity in an orthopedic clinic ${ }^{(10)}$. The application of gauze with cold saline solution significantly decreases the intensity of thirst in patients undergoing laparoscopic cholecystectomy ${ }^{(12)}$.

According to the reports of caregivers in this study, professionals did not use any strategies that used low temperatures. Such methods are effective and are based on the theory of pre-absorptive satiety that occurs by stimulating orophagyngeal receptors ${ }^{(15)}$. The ice reduces the intensity of thirst (in a scale from 1 to 10 ) from 6.13 to 1.51 in patients in the immediate postoperative period ${ }^{(11)}$. Besides being effective to relieve thirst, the use of ice prevents the ingestion of large volumes, preventing aspiration and it generates feeling of freshness and comfort ${ }^{(19)}$.

There isn't still any solid evidence about the best method for the relief of thirst in surgical patients, especially when it comes to pediatric patients. Also there is little research addressing security in the implementation of these strategies. There is a validated protocol that provides subsidies to assess such security, the Security Protocol for Thirst Management in Adults, which uses as criteria the level of patient awareness, airway protection and the absence of nausea and vomiting. The criteria were organized in the form of a graphic algorithm together with the operational procedures and operational manual ${ }^{(20)}$. Security protocols for children haven't been validated yet.

\section{Conclusion}

Addressing fasting and thirst is difficult and it causes suffering, both for children and their families. During the fasting period, thirst creates a considerable discomfort for children and is one of the main complaints of caregivers, due to its laborious management. Caregivers identify this symptom by children's complaint and by the physical signs that they show, such as lip dryness.

Caregivers feel helpless and do not know how to help, suffer along with the children to the extent of restricting their own food. It is noticed a lack of communication between professionals and children, although it is known that such an approach can bring benefits to the patient, to the caregiver and to the professional himself.

Thirst is a symptom that is little valued by the nursing staff. Even though there is scientific evidence about the safety of lower fasting time for liquids, according to reports from family members, health professionals act based on the old myth that fasting should not be broken at all. There has been little initiative on their part concerning children's thirst and, when they decide to employ some strategy to alleviate the symptoms, they act empirically, without using standardized methods. As nurses are professionals with great importance in this context, it is paramount the conduction of studies about efficient methods for thirst relief in children, for the education 
of health teams concerning the right management of this symptom.

This study had as its main limitation the conduction of interviews only with family members of children who underwent urgent surgeries. The small post-operative admission time of elective surgeries did not allow the participants' interview. Knowing the perception of those family members could show a different reality from that experienced by children who underwent an urgent surgery, because they face several discomforts, such as acute pain, separation from the family and prolonged admission time, which can influence in their responses to fasting and thirst. However, the results highlight which individual aspects of children are involved in the experience of thirst.

\section{Collaborations}

Campana MC contributed to the creation of the study, data collection, analysis and writing of the article. Fonseca LF contributed to the guidance of the study, writing and final review of the article. Lopes DFM and Martins PR contributed to the final approval of the version to be published.

\section{References}

1. Ministério da Saúde (BR). Portaria no 1823 , de 23 de agosto de 2012. Institui a Política Nacional de Saúde do Trabalhador e da Trabalhadora. [Internet]. 2012 [citado 2015 out. 8]. Disponível em: http://bvsms.saude.gov.br/bvs/saudelegis/ gm/2012/prt1823_23_08_2012.html

2. Silva LA, Secco IAO, Dalri RCMB, Araújo SA, Romano CC, Silveira SE. Enfermagem do trabalho e ergonomia: prevenção de agravos à saúde. Rev Enferm UERJ. 2011; 19(2):317-23.

3. Pimenta AM, Kac G, Souza RRC, Ferreira LMBA, Silqueira SMF. Trabalho noturno e risco cardiovascular em funcionários de universidade pública. Rev Assoc Med Bras. 2012; 58(2):168-77.
4. Andrade JP, Mattos LAP, Carvalho AC, Machado CA, Oliveira GMM. Programa nacional de qualificação de médicos na prevenção e atenção integral às doenças cardiovasculares. Arq Bras Cardiol. 2013; 100(3):203-11.

5. Sociedade Brasileira de Cardiologia. VI Diretrizes Brasileiras de Hipertensão. Arq Bras Cardiol. 2010; 95(Supl 1):1-51.

6. Barel M, Louzada JCA, Monteiro HL, Amaral SL. Associação dos fatores de risco para doenças cardiovasculares e qualidade de vida entre servidores da saúde. Rev Bras Educ Fís Esporte. 2010; 24(2):293-303.

7. Ministério da Saúde (BR). Estratégias para o cuidado da pessoa com doença crônica: hipertensão arterial sistêmica. Brasília: Ministério da Saúde; 2013.

8. Ministério da Saúde (BR). Hipertensão arterial sistêmica. Brasília: Ministério da Saúde; 2006.

9. Associação Brasileira para o Estudo da Obesidade e da Síndrome Metabólica. Diretrizes Brasileiras de Obesidade. Itapevi: AC Farmacêutica; 2009.

10. Sociedade Brasileira de Diabetes. Diretrizes da Sociedade Brasileira de Diabetes 2014-2015. São Paulo: AC Farmacêutica; 2015.

11. American Diabetes Association. Standards of medical care in diabetes 2014. Diabetes Care. 2014; 37(Supl 1):14-80.

12. Aguiar OB, Valente JG, Fonseca MJM. Descrição sócio demográfica, laboral e de saúde dos trabalhadores do setor de alimentação dos restaurantes populares do estado do rio de Janeiro. Rev Nutr. 2010; 23(6):969-82.

13. Cavagioni L, Pierin, AMG. Cardiovascular risk among health professionals working in prehospital care services. Rev Esc Enferm USP. 2012; 46(2):395-403.

14. Pretto ADB, Pastore CA, Assunção MCF. Comportamentos relacionados à saúde entre profissionais de ambulatórios do Sistema Único de Saúde no município de Pelotas, RS. Epidemiol Serv Saúde. 2014; 23(4):635-44. 
15. Couto MT, Pinheiro TF, Valença O, Machin R, Silva GSN, Gomes R. O homem na atenção primária à saúde: discutindo (in)visibilidade a partir da perspectiva de gênero. Interface Comun Saúde Educ. 2010; 14(33):257-70.

16. Fernandes ACP, Vaz AB. Perfil do índice de massa corporal de trabalhadores de uma empresa de construção civil. J Health Sci Inst. 2012; 30(2):1449.

17. Marziale MHP, Hong OS, Morris JA, Rocha FLR. The Roles and Functions of Occupational Health Nurses in Brazil and in the United States. Rev Latino-am Enfermagem. 2010; 18(2):182-8.

18. Farooq M, Tan K, Crowe S. Fasting times in caregivers of children presenting for ambulatory surgery. Pediatr Anaesth. 2008; 18(9):820-2.
19. Conchon MF, Fonseca LF. Ice and water efficiency in the management of thirst in the immediate postoperative period: randomized clinical trial. Rev Enferm UFPE On line [Internet]. 2014 [cited 2015 Apr 12]; 8(5):1435-40. Available from: http://www.revista.ufpe.br/revistaenfermagem/ index.php/revista/article/viewArticle/5839

20. Nascimento LA, Fonseca LF. Sede do paciente cirúrgico: elaboração e validação de um protocolo de manejo seguro da sede. Rev Enferm UFPE On line [periódico na internet]. 2013 [citado 2015 jan. 18]; 7(3):1055-8. Disponível em: http:// www.revista.ufpe.br/revistaenfermagem/index. php/revista/article/view/3920 